\title{
CUSTOMER RELATIONSHIP MANAGEMENT - THEORY AND PRINCIPLES
}

\author{
Miroslava Heczková, Michal Stoklasa
}

\section{Klíčová slova:}

řízení vztahů se zákazníky, relační marketing, analytické CRM, operativní CRM, kolaborativní CRM, databáze, malé a střední podniky.

\section{Key words:}

customer relationship management, relational marketing, analytical CRM, operative CRM, collaborative CRM, database, small and medium enterprises.

\begin{abstract}
Abstrakt
Cílem tohoto článku je prozkoumat teoretické poznání rrízení vztahů se zákazníky (CRM) a jeho princip fungování, aby mohly být nalezeny oblasti, kterými se autoři budou zabývat v navazujícím primárním výzkumu. Proto tento článek zkoumá vývoj definic CRM, od jejich úplných počátků v 90 . letech 20 . století po současnost. Na tomto vývoji autoři popisují, jak se měnil př́stup k CRM. Dále článek popisuje aplikační architekturu CRM, tedy analytické, operativní a kolaborativní CRM, a uvádí př́klad jejich fungování v praxi. Autoři také zmiňují výhody a nevýhody, které CRM přináší. Poslední část článku je věnována zamyšlení nad situací malých a středních podniků, zda tyto mají vůbec možnost CRM implementovat. V závěru článku autoři shrnují klíčové body vystupující z poznání teorie, které by měl obsahovat dotazník.
\end{abstract}

\begin{abstract}
This article aims to explore the theoretical knowledge of customer relationship management (CRM) and its operating principle, so it allows finding issues that need to be addressed in the following primary research. That is why this article examines the development of CRM definitions, from their very beginning in the 90 's of the $20^{\text {th }}$ century to the present. On this development, the authors describe the change in the approach to CRM. Furthermore, the article describes the application architecture of CRM, i.e. analytical, operational and collaborative CRM, and provides an example of their practical operation. Authors also mention advantages and disadvantages that are coupled with CRM. The last part of this article is devoted to reflection on the situation of small and medium enterprises, whether they even have the opportunity to implement CRM. In conclusion the authors summarize the key points arising from the theory, which should be included in a questionnaire.
\end{abstract}

\section{Introduction}

Marketing is a very dynamic discipline that constantly reacts to impulses of social-economic shifts and to needs of various entrepreneurial subjects. Successful can be only those companies that actively apply marketing approach to the market. Clearly stated marketing philosophy, thorough knowledge of the market, organization subject to a marketing strategy and sufficient timing advance in decision making are absolutely necessary for a company to operate in the EU market environment. Different companies though have different prerequisites, conditions and possibilities to utilize this approach fully and effectively. One of the limiting factors is the size of a company. Important parts of economical infrastructure of developed countries are small and medium sized enterprises that have fundamental influence on their entrepreneurial environment. 
Current small and medium sized enterprises take care of many different segments of local customers or even operate in the whole area of the European Union. However their customers are not willing to accept just any product, they require the best one with the highest added value. Current development of entrepreneurial environment coupled with simultaneous development of information and communication technologies even further intensify competition. That's why it is necessary for these companies to exercise modern marketing with strong emphasis on partnership with their customers and to be able to simply and centrally manage all processes, which then leads to fulfilment of their goals. That is the content of customer relationship management (further referred to as CRM). Jakubíková (2008, p.44) says: "The intention of customer relationship management is to build strategy of partnership which will help to cultivate this relationship and increase its value." This increased value subsequently brings a competitive advantage to the company and thus better position on the market.

This article aims to explore the theoretical knowledge of customer relationship management (CRM) and its operating principle, so it allows finding issues that need to be addressed in the following primary research. To fulfil this aim, the authors describe definitions of CRM and its functioning, its advantages and disadvantages and possibilities for small and medium enterprises to utilize it. All this information should be a basis for the following primary research and should provide specific points that need to be taken into account and areas that need to be researched. Based on this information a questionnaire will be created.

\section{Definition of CRM and its development}

Origins of the term CRM can be traced back to the 90's of the 20th century when the concept of marketing changed from transactional to relational (Dohnal, 2002, p. 31). Since the beginning, many definitions have appeared with different meaning and sometimes even the meaning of the acronym CRM varied from Customer relationship management to Customer relationship marketing (Buttle, 2009, p. 3). It is hard to verify who the first to define CRM was. Some sources claim that Lehtinen together with colleagues were one of the first to describe and thoroughly research CRM (Lehtinen, 2007, p. 18-19). According to Lehtinen (2007, p. 18) CRM came into being together with development of marketing which gradually became more personal until it transformed into direct customer marketing, also known as oneto-one marketing, which aims at individual customers. Therefore CRM implementation requires companies to change their view of marketing. Transactional (classical) marketing is becoming a thing of the past and the new trend is relational marketing, defined by Dohnal (2002, p. 32) as: "a process of identifying, establishing, maintaining, improving, and if necessary timely termination of economic relations with customers and other concerned subjects for the mutual benefit of all involved parties, which is achieved by mutual fulfilling of obligations and values.“

The outdated insight that product brings money to the company is slowly being changed into a new one that money is brought by the customer. Marketing mix of 4P's has been crucial in the past century: product, price, place and promotion. The main goal of employees has thus been to sell a product, literally to force it to the market, whatever its requirements have been. Nowadays, however, manufacturers and retailers focus on what the customer wants. They carry out research and design their products accordingly that customers buy them because it can solve their problems or can bring tangible benefits. In this context Chlebovský (2005, p. 18) writes even about crisis of marketing mix and sees the future in CRM. We can even note a 
transition to 4C's: customer cost, customer solution, convenience and communication (Kotler and Keller, 2007, p. 58).

Authors perceive Kotler as one of the most known propagators of marketing, with his books being used at many Czech universities, thus his marketing thoughts being close to Czech entrepreneurs managing the enterprises that are going to be subject to our further research. Kotler (1992, p. 731) mentioned relationship marketing for the first time only as a part of personal selling, by stating that: "the seller, who knows how to build strong relationship with customers will achieve many successful businesses in the future. Relationship management is a key skill that marketing professionals need." One of the first definitions of CRM by Kotler and Armstrong (2004, p. 248) specifies customer relationship management as: "a special software programmes and analytical techniques that serve for integration and utilization of vast amount of data about individual customers stored in databases. Customer relationship management consists of sophisticated software and analytical tools which sort customer's information from all sources, conduct thorough analysis and use these outcomes for strengthening the relationship with the customer."

From this initial decade of CRM evolution, authors understand CRM as a process of continuous gathering, processing and following utilization of customer data, that works on the basis of database technology and is done by a software programme. This activity enables the company to understand needs, wishes and purchase habits of its customers. Some of this data might be used to foresee future opportunities. This understanding is agreed on by other authors reviewing this issue (Starzyczná and Pellešová, 2005, p. 155). But as Starzyczná and Pellešová (2005, p.155) further note: "customer relationship management is something much more".

The trend of CRM evolving into something more can be manifested by the definition of Dohnal (2002, p. 18): “Customer relationship management includes employees, company processes and IS/ICT technology with the main goal to maximize customer loyalty and thus company profitability. It is a part of company strategy, which makes it a part of company culture." But as Buttle (2009, p. 22) points out, this loyalty must not be misunderstood as just a loyalty programmes. This common mistake can be seen in many surveys and researches, e.g. Wojnarowska (2007, p. 171-173) does not differentiate between CRM and loyalty programmes. Authors understand this as a necessity to differentiate between these two in their further research. Storback and Lehtinen (2002, p. 18) even mention that: "The goal of customer relationship management is not to be close to a customer but to live with him". Lehtinen (2007, p. 82-83) further elaborates on the issue of customer with the thought, that the intention of CRM is to establish long-term relations with customers, not pursuing maximization of short-term income, but recognizing strategic customers. Authors see this thought of focusing on key customers as very important.

Newer definitions understand CRM as a broader term, e.g. Peelen (2005, p. 6) states: "CRM is to be regarded as a business strategy that is aimed towards developing long-term, mutually profitable, individual customer-supplier relationships and is placed on an IT infrastructure to be developed, one that enables well-defined and controlled processes, and places capable personnel in a position to function optimally." Many authors agree to CRM being an important business strategy, e.g. Buttle (2009, p. 22) wrote: "CRM is the core business strategy that integrates internal processes and functions, and external networks, to create and deliver value to targeted customers at a profit. It is grounded on high quality customer-related data and enabled by information technology." Some authors disagree with CRM being a new 
way of marketing, e.g. Tomek and Vávrová (2012, p. 157) conclude that for successful CRM a company does not need anything else than every employee having customer as their primary target. Other researchers conclude as well that CRM should be mainly perceived as a philosophy of a company and not just a computer programme. According to Starzyczná and Pellešová (2007), the bases for CRM are two things: customers, who are unique to each company, and company culture.

A view on CRM development according to Veber (2009, p. 495) can be summarized into the following phases of CRM utilization:

- Pre-pre-CRM stage: business initiative is up to the customer, companies respect basic technical and warranty requirements

- Pre-CRM stage: sales department is the leading department in a company, marketing department is only following, profit is main motivator and that creates pressure on the costs

- Basis for CRM: traditional marketing focused on product and marketing mix

- $1^{\text {st }}$ CRM stage: reactive approach to the customer, evaluation of his satisfaction

- $2^{\text {nd }}$ CRM stage: pro-active approach to the customer creates win-win relationship, CRM software is becoming important and company focuses on customers values

According to Matušínská (2009, p. 193), the next "evolutionary" form of CRM could be VCRM (Value Customer Relationship Management) which is basically CRM based on values or VKCRM (Value Key Customer Relationship Management) which is CRM that prioritizes communication with key customers. According to Matušínská (2009, p. 193) these systems will mainly prioritize the swiftness of processing questions (speed), detailed knowledge of the customer (access to data), immediate solution of problems (one-and-done), personalization (customized contacts), no waiting for assistance (direct help), functioning 24 hours a day, 7 days in a week (all time), complex ways of sales (multi-channel-strategy), direct contact with a customer (one-to-one), single contact person (one-touch-point) and other.

As has been mentioned, CRM is present in the marketing theory for two decades, but only in the last decade its perception made a huge shift from narrowly specialized utilization and focus on technical aspect to mass utilization in all areas of company management and the focus on philosophy, one that truly places customer in the centre of company's activities. This shift is especially noticeable in the Czech Republic for some reasons: market deregulation connected with our EU accession, new business models taken from the "west", internet penetration and technological progress. It should also be pointed out that CRM is an interdisciplinary issue that affects all workers and all departments of the company. Merely linking CRM with information technology is wrong. The successful implementation of customer relationship management is also dependant on quality strategy, process management, corporate culture and quality of the management. The trend in the development of theoretical definitions confirms this idea.

The research of Starzyczná and Pellešová (2007), regarding the CRM knowledge of Czech companies doing business in services, found out that the CRM is perceived as: "the creation of a permanent relation with customers, which brings a long-time value for both participants of this relation." This definition is very close to how authors see the basic principle of CRM as a great analogy to how business has been done in the past millennia. Cities have been relatively separated and beside few travelling traders the customers were always the same ones. Clever traders knew these customers and all their needs and wishes that travelling 
traders couldn't know. These local traders then adapted all their business activities to their customers.

\section{Parts of CRM}

The complete description of how CRM functions in a company would be too complex, that is why authors only describe basic division into parts and their characterization. Buttle (2009, p. 3,22 ) calls this "types" of CRM, but other authors incline to a view by Dohnal (2002, p. 59) that describes this as three parts of CRM application architecture: analytical, operative and collaborative. In order for any action in CRM to be successful it requires consistent data about customers which will be accessible to every employee of a company. That is also highly demanding on a technology providing CRM in a company.

\subsection{Analytical CRM}

The purpose of analytical CRM is customer data analysis, its evaluation, modelling and prediction of customer behaviour. (Dohnal, 2002, p.63) In real life situation the analytical CRM can for example gather all the data about customers inquiring a specific product by using data mining (tool for data gathering), what services they purchased right away and what services they purchased eventually. It can find patterns in their behaviour and propose next steps during up-selling or cross-selling. It can evaluate efficiency of a marketing campaign, propose prices or even develop and propose new products. This way analytical CRM serves as some sort of help during decision making, e.g. manuals for employees working in services concerned with how to react to certain customer's behaviour.

\subsection{Operative CRM}

Operative CRM mainly supports the actual contact with customers conducted by front office workers and general automation of business processes including sales of products, services and marketing. All communication with the customer is tracked and stored in the database and if necessary it is effectively provided to users (workers). (Dohnal, 2002, p. 60) The advantage of this approach being the possibility to communicate with various employees using various channels but creating the feeling that customer is being taken care of by just one person. It can also minimize the time that the worker has to spend typing the information and administrating (the data is shared). This allows the company to increase the efficiency of their employees work and they are then able to serve more customers.

\subsection{Collaborative CRM}

Collaborative CRM enables all companies along the distribution channel, as well as all departments in a company, to work together and share information about customers (Dohnal, 2002, p. 63-64). Buttle (2009, p. 11) even speaks about partner relationship management (PRM). But sometimes we might see a rivalry between departments that undermines efforts of CRM to share relevant data throughout the whole company (e.g. information from help line can help the marketing department choose a point on which it will focus during the next campaign). The goal of collaborative CRM then is maximum sharing of relevant information acquired by all departments with the focus on increasing the quality of services provided to customers. The ultimate outcome of this process should be an increase in customer's utility and his loyalty (Edwards, 2007, online).

Information technology plays an important role in the concept of CRM. Without its smooth function the modern CRM would be unimaginable. But it is not only the technology that is important. Company must be willing and able to adopt the whole philosophy which puts the 
main focus on the customer. It must adopt the strategy focused on establishing and supporting long-term relationship with customers. Failure in following this philosophy and strategy leads to a failure of whole CRM implementation. (Dohnal, 2002)

An example will demonstrate the entire CRM process and its use. The basis of every CRM system is data about customers that is stored transparently by all departments in one huge data warehouse. Analytical CRM works with this data. It processes this data and automatically performs basic tasks, analyses patterns of customer's behaviour and makes predictions. It transforms the data into information. The information is sent to operative component where front office workers put it into use. It allows that information to be used for efficient and personalized interaction with clients. These three steps are observed by back office workers which influence them and are influenced by them (e.g. creation of a new suitable product). Information from operative CRM is readily available to any employee through collaborative CRM. Customer sees this system as an activity geared up to him and reacts to it. This reaction then influences the whole process which thanks to this input continues to work. All this illustrates the diagram in Figure 1.

\section{Figure 1}

Technological aspects and principles of CRM

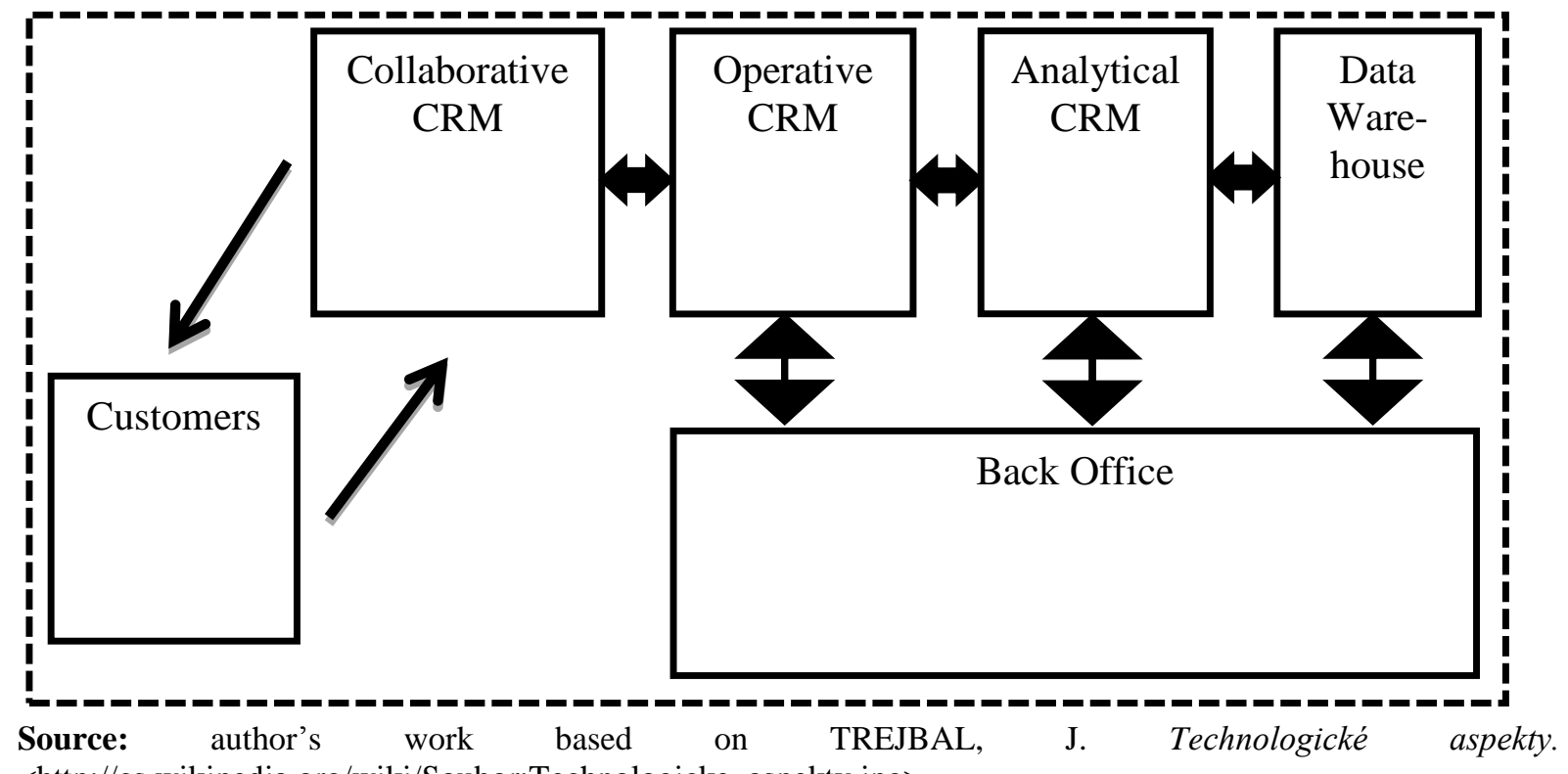

<http://cs.wikipedia.org/wiki/Soubor:Technologicke_aspekty.jpg>

\section{Advantages and benefits of CRM}

Certainly a benefit for each company is to achieve better economic results thanks to achieving higher value from every interaction with a customer. Competition is very sharp in current market. Companies must take care of a customer in every area of their specialization by using various communication channels. Customer expects perfect services whether he calls a help line, asks a dealer, browses a web site or personally visits a store. It is necessary to assure him in a feeling that he communicates with the same company whatever form of communication, time or place he chooses. According to Matušinská (2009, p. 191) the basic advantages and benefits of CRM are these:

- $\quad$ satisfied customer does not consider leaving

- product development can be defined according to current customer needs

- a rapid increase in quality of products and services 
- the ability to sell more products

- optimization of communication costs

- proper selection of marketing tools (communication)

- trouble-free run of business processes

- greater number of individual contacts with customers

- more time for customer

- differentiation from competition

- real time access to information

- fast and reliable predictions

- communication between marketing, sales and services

- increase in effectiveness of teamwork

- increase in staff motivation

Advantages and benefits are almost endless. Unfortunately some negatives exist. One of them is the fact that proper implementation and running of CRM is very difficult (technology, people - employees, initial money investment etc.), another one is the safety of information that companies keep about their customers, sharing information with third party and its overall protection. The entire operating principle of CRM (gathering information, recording calls, analyzing all clients' activities etc.) is invasion of privacy of customers.

For effective relationship management it is necessary for a company to not only hold onto their perspective but also try to understand why it is beneficial for a customer to establish a long term relation. Customer always cares primarily about satisfaction of his needs. If a company wants to establish mutual long-term relationship it must offer him something extra, some "reward" that will give him the desired value. The success rate of company being able to satisfy this desired value represents the quality of CRM. One hundred percent success rate is rarely achieved. However if the success rate in "rewarding" is acceptable then the customer continues in the relationship (makes further purchases).

\section{Currently used CRM solutions}

Buttle (2009, p. 369-371) divides CRM solutions into three groups: enterprise CRM suites, midmarket CRM suites and CRM specialty suites. The list of companies providing these solutions is very long, that is why authors will not focus on the exact CRM product, but will rather focus on the method of purchasing and functionality. Functionality is divided by Buttle (2009, p. 393) into three wide groups: sales-force automation, marketing automation and service automation. Dohnal (2002, p. 69) calls this the division by business channels. As far as methods of purchasing are concerned, there are currently two different solutions of CRM system: self-owned and hosted (Švec, 2010, online). Self-owned system is a system that is installed locally. The advantage of this solution is the possibility to fine-tune it directly to company's needs and independency on any provider. Disadvantages are overall costs, problems with implementation, necessity to own hardware, training of employees etc. Hosted system is convenient for small and medium enterprises. Basically it is the right to use a service offered by some CRM company (SaaS - Software as a Service). Setting up this system is fast and simple, there is no need to buy any hardware and there are no time and financial costs with implementation and operation. On the other hand there are some disadvantages such as dependency on the provider, inability to adjust the system to certain needs and necessity to always be online. 
Currently used CRM solutions in Czech Republic are (CRMFORUM, 2009, online): Microsoft dynamics CRM, Bluejet web CRM, SugarCRM, Epiphany by Infor, CAS PIA and other.

\section{Integration of CRM into management of small and medium enterprises}

Size of a company affects the way how all operations and processes are done. That is also true for how CRM is used in customer's care. "Small and medium enterprises are owned and managed independently and are not dominant in their field of operation. They are separate entities in the hands of one or more entrepreneurs with limited number of employees, relatively small production capital and annual turnover (Small Business Act, 1953)." This original (still up-to-date) definition has set current division of small and medium enterprises, which is applicable for all EU countries since 1 January 2005 (see Commission Regulation (EC) No 364/2004, online, p. 6). This methodology uses four criteria for company classification: number of employees, annual sales (incomes), asset value (property value), and independence $^{1}$. Basic characteristics of these companies can be defined as follows:

- independent management coupled with independent ownership

- capital is owned by one or several owners

- predominant focus on local markets

- simple management system (horizontal structure)

- company is small compared to major competitors

Knowing the dimensions of problems that these companies have we can say that usage of marketing tools has its specifics and nuances. Individual elements of marketing tools are not only means for satisfaction of a customer but also a possibility to differentiate from competition and achieve competitive advantage. Marketing can be understood in this context from different perspectives - it is a business philosophy, it is a system of business functions and finally it is a marketing of relations.

In this context one of the most efficient ways to differentiate from competition is to understand individual customers and their needs. Personal approach and excellent services are necessity. This is particularly true for the category of small and medium enterprises. That is why it is so important and essential for them to use CRM in their management.

Before any small or medium enterprise will start its considerations about the form and method of strategic marketing management it must realize the fact that if there is no precise definition of target market then the follow up activities are completely pointless. The choice of target market is the outcome of market research and subsequent segmentation. So if a company has clearly specified area of activity it may proceed with the development of marketing strategy. The problem in small and medium enterprises in this respect is that due to its size and organization structure often a single person (usually the owner) has to exercise many activities. He often lacks adequate skills and competence which leads to his overload and consequent errors in decision making and managing.

\footnotetext{
${ }^{1}$ Micro enterprise: employ fewer than 10 persons, annual turnover not exceeding 2 million euro, and/or an annual balance sheet total does not exceed EUR 2 million.

Small enterprise: employ fewer than 50 persons, annual turnover not exceeding 10 million euro, and/or an annual balance sheet total does not exceed EUR 10 million.

Medium enterprise: employ fewer than 250 persons, annual turnover not exceeding 50 million euro, and/or an annual balance sheet total does not exceed EUR 43 million.
} 
It is clear that nowadays almost every small and medium enterprise in some way respects requirements of its customers but not all of them base their activities on them. To ensure the success of a company in the market and its competitiveness it must really be based on customer's wishes and needs and not just respect them. Competitive advantage can't be viewed as a quality product or low price anymore. Company must be able to offer the value that the customer wants in the whole package - quality product, reasonable price, additional services and after-sale care. Due to the orientation of company's management on the process and providing value to the customers the transactional view of marketing is becoming obsolete and is pushed out by the relational approach. It is therefore essential that small and medium enterprises implement CRM into their strategic marketing management.

Especially problematic is perception of CRM in micro enterprises (companies with fewer than 10 employees). An example of how to grasp this problem and use CRM in conditions of such a company is the following fictional example "Henrys General Store". This example is based on the theoretical basis of this article and practical knowledge of authors.

Henry is a young entrepreneur who owns a general store located in an urban settlement. But it's no ordinary general store. Henry knows his regular customers and takes good care of them. Customer Eduard is approaching the store and Henry sees him from the window (process of identification). Eduard enters the store and Henry kindly greets him and addresses him by his name (personalization). Henry remembers what Eduard usually buys, that he has a wife and two kids (customer data). During the shopping Henry talks with Eduard and gently tries to gather additional information (establishing relationship, possibility for cross-selling, analysis). Eduard appreciates the interest and personal approach and returns often to this store. Henry is thanks to all this information always able to offer him exactly the goods he needs. Another advantage for Eduard is the time saving if he is in a hurry because Henry knows his needs and can serve him faster as well as allow him to leave a debit (trust based on long-term relationship).

This example could be used in the following research as an illustrative example for description of CRM to the entrepreneurs, who have never heard about this term. How many of the Czech small and medium enterprises do not utilize CRM is documented by the results of a survey published by the Czech Statistical Office (2010, online). Figure 2 shows the dependency of CRM usage on the size of a company. Clearly visible difference (19\% for micro companies and $62 \%$ for large companies) stems from obstacles (such as technical, financial, personal etc.) which only large companies can overcome (it pays out thanks to economy of scale).

The survey also indicates some other interesting information: companies use CRM mainly for gathering, storing and accessing data about customers for all their departments (18\% of all companies) and marketing activities (14\% of all companies). CRM is mainly used in services. Czech companies are still below EU average (by 6\%) of CRM utilization. 
Figure 2

CRM utilization based on the size of an enterprise

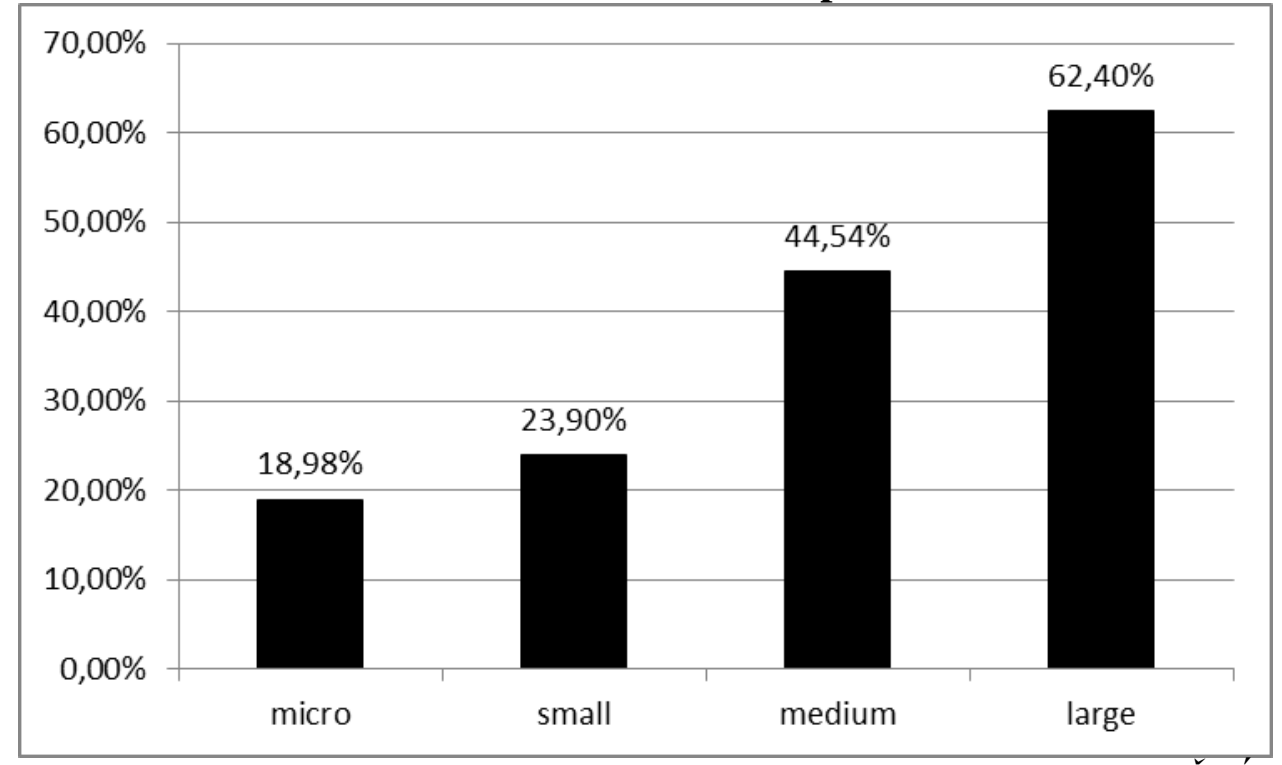

Source: Information technology in corporate sector, $\check{C} S U$ [online]. 2010 http://www.czso.cz/csu/redakce.nsf/i/2_z_elektronicke_vymeny_dat_tezi_hlavne_velke_podniky

So if a small or medium enterprise wants to use CRM as a source of competitive advantage it must focus on establishing long-term relationship with its customers. This establishing of relations has some costs that can cause decrease in short-term profit. That's why it is necessary to view application of CRM from the perspective of future long-term increase in profits. If a company relinquishes short-term profit on behalf of a valuable relationship with a customer it will be rewarded by the existence of stable long-term potential for profit increase. The primary goal of entrepreneurship is still a profit but from the CRM perspective it's a profit that can fluctuate in time and is "visible" mainly in long-term.

In conclusion we must emphasize that implementation in small and medium enterprises can't be perceived purposelessly just for having one of those systems. The goal must always be to adopt the whole philosophy and adopt it in the way that it increases the number of satisfied and loyal customers, optimizes costs of sales and achieves competitive advantage.

\section{Conclusion}

Definitions of customer relationship management have gradually changed as CRM was becoming more tangible and sizeable strategic management. They evolved from the original focus on technical aspect to current orientation of the whole company on a philosophy of establishing effective long-term relationship with customers. The authors see a big analogy of this approach to the way how business has been done in past millennium. Nowadays the advanced CRM systems allow even global companies to apply the knowledge of an individual customer locally which enables them to get to him as close as possible. The progress subsequently allows small and medium enterprises to get these procedures and know-how of large companies. Thanks to this progress it should even be possible that micro companies can adapt the advantages of CRM systems. The authors perceive this as a final piece of a circle and logical coming to the system that always has had and always will work.

The following research needs to address some key points that arose from this article. These key points are: how enterprises define CRM, what is their understanding of CRM (ranging 
from a simple software programme to the company philosophy), do they perceive loyalty programmes as a part of CRM, do they know their key customers, do they have enough information about their key customers, do the enterprises understand analytical, operative and collaborative CRM, what are the advantages and disadvantages that these enterprises realize form having CRM, what is the functionality they seek, did they think about self-owned or hosted CRM. A questionnaire should be created that will include questions addressing these key points.

\section{References}

[1] BUTTLE, F. Customer relationship management: concepts and technologies. Oxford: Elsevier, 2009. ISBN 978-1-85617-5522-7.

[2] DOHNAL. J. Ř́zení vztahů se zákazníky. Praha: Grada Publishing, 2002, ISBN 80247-0401-3.

[3] CHLEBOVSKÝ, V. CRM - řízení vztahů se zákazníky. Brno: Computer Press, a.s., 2005. ISBN 80-251-0798-1.

[4] JAKUBÍKOVÁ, D. Strategický marketing. Praha: Grada Publishing, 2008. ISBN 97880-247-2690-8.

[5] KOTLER, P. Marketing management: Analýza, plánování, využití, kontrola. 7. vyd. Praha: Victoria Publishing, 1992. ISBN 80-85605-08-2.

[6] KOTLER, P., ARMSTRONG, G. Marketing. Praha: Grada Publishing, 2004. ISBN 80247-0513-3.

[7] KOTLER, P., KELLER, K.L. Marketing management. Praha: Grada Publishing, 2007. ISBN 978-80-247-1359-5.

[8] LEHTINEN, J.R. Aktivní CRM. Řízení vztahů se zákazníky. Praha: Grada Publishing, 2007. ISBN 978-80-247-2439-3.

[9] MATUŠÍNSKÁ, K. Marketing finančních služeb. Karviná, 2009. ISBN 978-80-7248520-8.

[10] PEELEN, E. Customer relationship management. Pearson Education, 2005. ISBN 978 0-273-68177-9.

[11] STARZYCZNÁ, H. a kol. Metodologie marketingu vztahů a její postavení v rámci strategického marketingu a rrízení vztahů se zákazníkem (CRM) - praktické využití. Karviná, 2007. ISBN 978-80-7248-451-5.

[12] STARZYCZNÁ, H., PELLEŠOVÁ, P. Teoretická východiska ř́zení vztahů se zákazníky - customer relationship management. In Acta academica karviniensia. Karviná: SU OPF, 2005. ISSN 1212-415X.

[13] STARZYCZNÁ, H., PELLEŠOVÁ, P. The awareness level of CRM in Czech production organizations and services. In Acta academica karviniensia. Karviná: SU OPF, 2007. ISSN 1212-415X.

[14] STORBACK, K., LEHTINEN, J.R. Rízení vztahů se zákazníky. Customer Relationship Management. Praha: Grada Publishing, 2002. ISBN 80-7169-813-X.

[15] TOMEK, G., VÁVROVÁ, V. Vize tržního úspěchu: aneb 10 otázek a odpovědí jak chápat marketing budoucnosti. Praha: Professional Publishing, 2012. ISBN 978-807431-071-3.

[16] VEBER, J. a kol. Management, základy, moderní manažerské přístupy, výkonnost a prosperita. Praha: Management Press, 2009. ISBN 978-80-7261-200-0.

[17] WOJNAROWSKA, H. Customer relationship management as a factor increasing corporate market value of polish companies. Selected aspects of the results of research. In Acta academica karviniensia. Karviná: SU OPF, 2007. ISSN 1212-415X. 


\section{Online references}

[18] Commission Regulation (EC) No 364/2004 [online]. 2004-02-25 [cit. 2010-09-12]. Available at: 〈http://download.mpo.cz/get/26545/29056/315705/priloha007.pdf〉.

[19] Dostupná CRM řešení na českém trhu - soubor článků. CRMFORUM [online]. 2009 [2010-09-14]. Available at: <http://www.crmforum.cz/crm-reseni/>.

[20] EDWARDS, J. Get it together with collaborative CRM. INSIDECRM [online]. 200710-29 [cit. 2010-09-30]. Available at: <http://www.insidecrm.com/features/collaborative-crm-112907/>.

[21] Informační technologie v podnikatelském sektoru. ČSÚ [online]. 2010-02-16 [cit. 201009-26]. Available at: 〈http://www.czso.cz/csu/redakce.nsf/i/podnikatelsky_sektor>.

[22] ŠVEC, P. CRM systémy - co nabízí český trh. ITBIZ [online]. 2010-02-09 [cit. 201009-12]. Available at: 〈http://www.itbiz.cz/crm-systemy-co-je-dnes-na-trhu〉.

[23] TREJBAL, J. Schéma Technologické aspekty [online]. 2008-05-27 [cit. 2010-09-14]. Available at URL: 〈http://cs.wikipedia.org/wiki/Soubor:Technologicke_aspekty.jpg>.

Klasifikace JEL: M31, M15, M21

Ing. Miroslava Heczková, Ph.D.

Odborný asistent Katedra marketingu

Slezská univerzita v Opavě

Obchodně podnikatelská fakulta v Karviné

Univerzitní náměstí 1934/3, Karviná

heczkova@opf.slu.cz

Ing. Michal Stoklasa

Odborný asistent Katedra marketingu

Slezská univerzita v Opavě

Obchodně podnikatelská fakulta v Karviné

Univerzitní náměstí 1934/3, Karviná

stoklasa@opf.slu.cz 